\title{
Molecular Evidence of Recombination on Korean Isolates of Tomato yellow leaf curl virus by Nucleotide Transversions and Transitions
}

\author{
Hyejung Lee', Jungan Park ${ }^{1}$, Chung-Kyoon Auh², Kyeong-yeoll Lee ${ }^{3}$, Chang-Seok Kim ${ }^{4}$, Gwan-Seok Lee, \\ Hyuncheol Soh ${ }^{1}$, Hong-Soo Choi ${ }^{4 *}$ and Sukchan Lee ${ }^{1 *}$ \\ ${ }^{1}$ Department of Genetic Engineering, Sungkyunkwan University, Suwon 440-746, Korea \\ ${ }^{2}$ Department of Biological Sciences, Mokpo National University, Muan 534-729, Korea \\ ${ }^{3}$ Department of Agriculture Biology, Kyungpook National University, Daegu 702-701, Korea \\ ${ }^{4}$ Department of Agricultural Biology, National Academy of Agricultural Science, Suwon 441-707, Korea \\ (Received on July 20, 2011; Revised on August 27, 2011; Accepted on August 28, 2011)
}

Tomato yellow leaf curl virus (TYLCV), a member of genus Begomovirus, was isolated in Korea in 2008. We sequenced and analyzed the DNA-A of 51 TYLCV isolates from Korea, and 13 of the TYLCV isolates were selected as type representatives of TYLCV from six Korean provinces. The 13 TYLCV isolates were classified into Korea Group 1 (KG1, nine isolates) and Korea Group 2 (KG2, four isolates) based on the results of phylogenetic analysis and genome size (2774 and 2781 nucleotides, respectively). A recombination detection program 3 (RDP3) revealed two recombinations between the TYLCV Korea isolates and other TYLCV isolates [Thailand (AF206674), Iran (AJ132711), and Israel (X76319)]. TYLCV Jeju isolate was characterized by two recombination events ( $E 1$ and E2) caused by the presence of E1 in ORF V1 and C3, which may seem to be the mutations of the high nucleotide transversion and transition rate. Collectively, our results suggest that the occurrence of nucleotide transversions and transitions in TYLCV DNA-A might have induced novel recombination events within the TYLCV Korea isolates.

Keywords : molecular phylogeny, mutation, nucleotide transversions, recombination, RDP3, TYLCV

There is genetic diversity within viral population since viruses have been evolved to adapt to new hosts and to changing environment. This process occurs via four major processes: recombination, mutation, reassortment, and de novo gene acquisition (Padidam et al., 1999). Natural re-

\footnotetext{
*Corresponding authors

S Lee

Phone) +82-31-290-7866, FAX) +82-31-290-7892

E-mail) cell4u@skku.edu

HS Choi

Phone) +82-31-290-0431, FAX) +82-31-290-0430

E-mail)hschoi@korea.kr
}

combination has been shown to occur in both RNA and DNA genomes and performs important functions in the evolution of animal and plant viruses at the strain, species, genus, and family levels (Briddon et al., 1996; Fondong et al., 2000; Klute et al., 1996; Sanz et al., 2000; Saunders and Stanley, 1999). Plant RNA viruses are more genetically stable than animal RNA viruses but geminiviruses evolve faster than some plant RNA viruses, including tobamoviruse and criniviruses (Duffy et al., 2008). Recombination events in geminiviruses with single-stranded DNA (ssDNA) genomes have been previously reported in a number of viruses, including studies of the African cassava mosaic virus (Fondong et al., 2000), East African cassava mosaic virus (Zhou et al., 1997), Cotton leaf curl virus (Zhou et al., 1998), Pepper huasteco virus (Bonilla-Ramirez et al., 1997; Torres-Pacheco et al., 1993), and Tomato leaf curl virus (ToLCV) (Umaharan et al., 1998). These recombination studies have spurred greater interest in the relationships between the frequency and role of recombination events and the microevolution of new geminiviruses. Recombination is an important genetic evolutionary mechanism in viruses but background mutation pressure must also be a key element of geminivirus evolution (Duffy et al., 2008).

Homologous recombination between two strains or isolates may result in the production of more virulent or viable viruses. However, non-homologous recombination facilitates the rearrangement of cellular or other viral genes via insertion (Padidam et al., 1999). A recent controlled study of the host variability of TYLCV in China demonstrated an average mutation frequency of approximately $3.5 \times 10^{-4}$ per base over 60 days of infection of a tobacco plant (Ge et al., 2007). This frequency is similar to that reported previously for plant RNA viruses, including Tobacco mosaic virus, Cucumber mosaic virus, and Cowpea chlorotic mottle virus (Schneider and Roossinck, 2001). TYLCV recombination was actively studied in the 2000s (Davino et al., 2009; Monci et al., 2002; Navas-Castillo et al., 2000). Navas- 
Castillo et al. (2000) determined that TYLCV Israel (X15656) and TYLCV Iran (AJ132711) isolates originated as chimeric genomes generated via recombination between TYLCV-Is-like (AF071228) and ToLCV-like ancestors (AF165098). A recombination event between geographically distinct Tomato yellow leaf curl Sardinia virus (TYLCSV, Z25751) and TYLCV (AF071228) has also been reported (Monci et al., 2002). And Davino group described that natural recombination between TYLCSV (X61153) and TYLCV (DQ144621) in mixed infections have been detected from tomato plants (Davino et al., 2009). In a field survey conducted in 2004, they showed that the TYLCV intergenic region (IR) was amplified from infected plants, and hybrid between the two species were found, but only in plants where one or both parental species were also present. Some hybrid viruses have a hybrid Rep protein, with the 202 amino-terminal amino acid from TYLCV and the remaining 155 amino acid from TYLCSV. Therefore replication assays in leaf disc indicated a lower replicative capacity with respect to parental viruses. Recently it has been reported that recombinants can be detected in tomatoes infected by TYLCSV and TYLCV under controlled conditions (Garcia-Andres et al., 2007). They suggested that recombinants are probably created

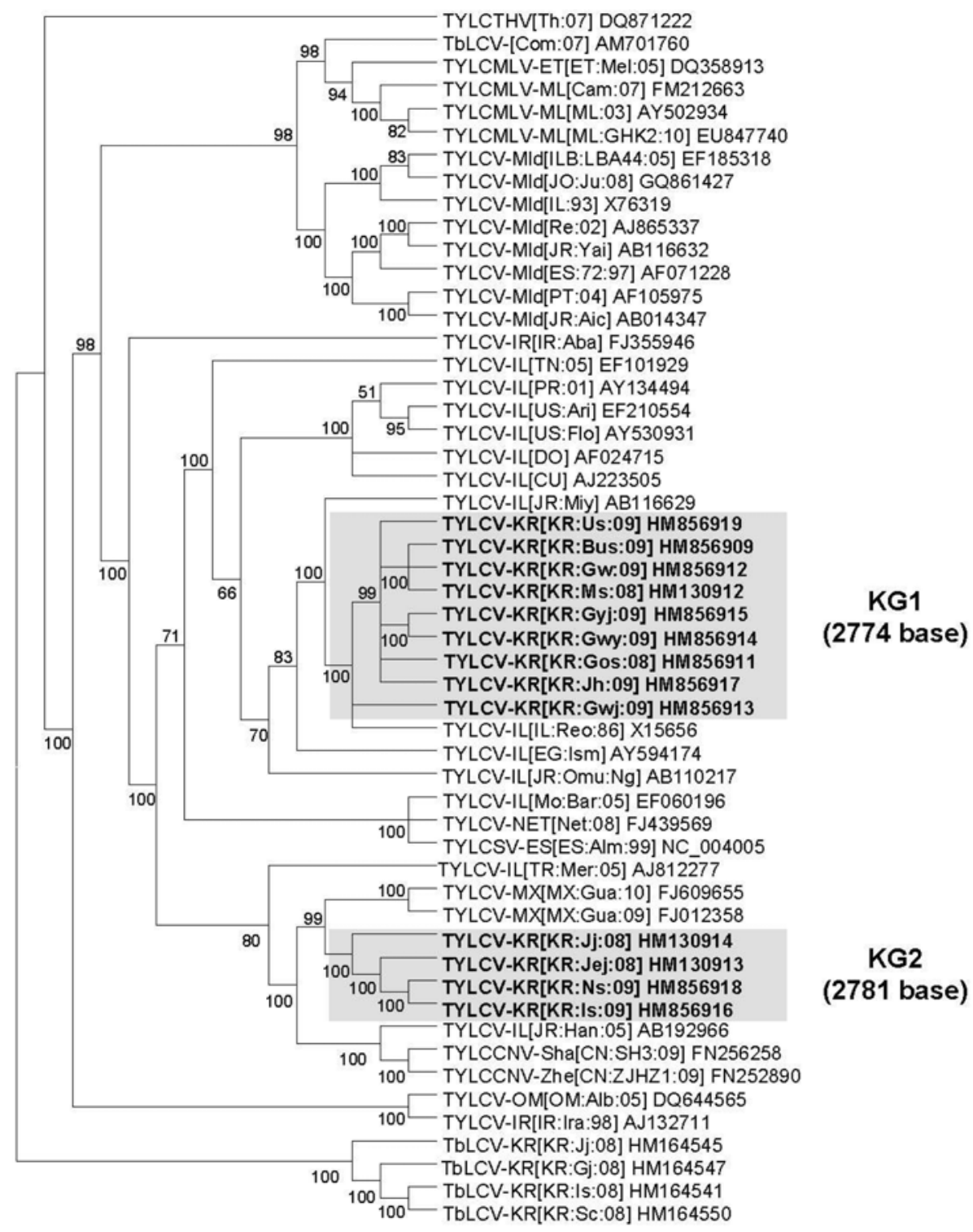

Fig. 1. Phylogeny of TYLCV full viral genome sequences obtained via neighnbor-joining method. TYLCV-Kr isolates were clustered into two distinct groups; KG1 and KG2. KG1 included isolates from Masan (HM130912), Busan (HM856909), Goseong (HM856911), Gyeongju (HM856915), Gunwi (HM856912), Uiseong (HM856919), Gwangyang (HM856914), Jangheung (HM856917), and Gwangju (HM856913). KG2 contained isolates from Jeju (HM130914), Nonsan (HM856918), Iksan (HM856916), and Jeonju (HM130913). 
continuously and frequently in the field when TYLCSV and TYLCV are present in the same plants (Davino et al., 2009).

The casual agent of tomato leaf curl disease (ToLCD) appeared in central Sudan could derive via an interspecies recombination event among three monopartite begomoviral genomes, Tomato leaf curl Sudan virus (ToLCSDV-[Gez] and ToLCSDV-[Sha]) and Tomato yellow leaf curl virusSudan (TYLCV-SD) (Idris and Brown, 2005). Here, we present evidences suggesting the possible occurrence of a recombination event due to nucleotide transversions within TYLCV Korea isolates.

TYLCV-infected tomatoes were collected from 51 greenhouses in Korea between 2008 and 2009, and 51 full TYLCV DNA-A sequences were obtained (Lee et al., 2010). Thirteen TYLCV DNA-A sequences, representing four provinces in Korea, were registered in GenBank, and these DNA sequences were employed for phylogenetic analysis and recombination studies. Forty-seven TYLCV sequences, including 13 TYLCV-Kr isolates and 5 Tobacco leaf curl virus (TbLCV) isolates that were used as outgroups, were obtained from GenBank. These sequences were aligned with the multiple sequence alignment program MUSCLE (Edgar, 2004), and were also analyzed via Neighbor-joining method (Kim et al., 2010; Saitou and Nei, 1987). Consensus trees were visualized using MEGA 4.0 (Choi et al., 2011; Tamura et al., 2007). Putative recombinant genomes were identified using the Recombination Detection Program 3 (RDP3) package, which contains seven recombination detection programs: Original RDP, Geneconv, MaxChi, Chimaera, Bootscan, SiScan, and 3Seq (Jonson et al., 2009; Martin et al., 2010). The default detection thresholds were used in all cases and the highest satisfactory $P$ value cut-off was set to 0.05 . DNA sequences (positions $1-$ 1950) of five isolates from the TYLCV Korea Group 2
(KG2) phylogenetic cluster [Jeju (HM130914), Jeonju (HM130913), Nonsan (HM856918), and Iksan (HM856916)] were selected for multiple sequence alignment using the Multi-Align program (http://multalin.toulouse.inra.fr/multalin/ multalin.html).

Phylogenetic analysis of the TYLCV isolates demonstrated that the TYLCV-Kr isolates were clustered into two distinct groups, $\mathrm{KG} 1$ and $\mathrm{KG} 2$. KG1 contained isolates with 2774 nucleotide genomes from nine regions in Gyeonsang-do and Jeolla-do. KG2 comprised isolates with 2781 nucleotide genomes from four regions in Jeju-do and Jeolla-do in Korea (Table 2). Therefore, the KG1 and KG2 isolates differed in their genome sizes (Fig. 1). The Bayesian consensus phylogeny showed that KG1 and KG2 were related closely to the TYLCV Japan isolates (AB192966 and AB116629) (Fig. 1). The KG1 isolates had highest sequence identities with TYLCV Japan Miyazaki (AB116629) and TYLCV Israel (X15656 and AY594174). $\mathrm{KG} 2$ isolates branched from the node containing isolates from Mexico (FJ609655 and FJ012358), and TYLCV isolates from Japan Haruno (AB192966) branched from the KG2 and TYLCV Mexico isolates (Fig. 1). Lefeuvre et al. (2010) suggested that TYLCV may have been introduced into the New World from East Asia, on the basis of the results of phylogenetic analyses of both the TYLCV coat protein and the full genomes. TYLCV Korea and Japan isolates may be intermediate in phylogenetic position between Old World and New World isolates.

Recombination detection analysis was carried out for the full 53 genome sequences of TYLCV and TbLCV. TYLCV isolates from Korea showed evidence of two recombination patterns. One pattern included one recombination event (E2), while the other included two recombination events (E1 and E2) (Fig. 2). Recombination event 1 (E1) involved

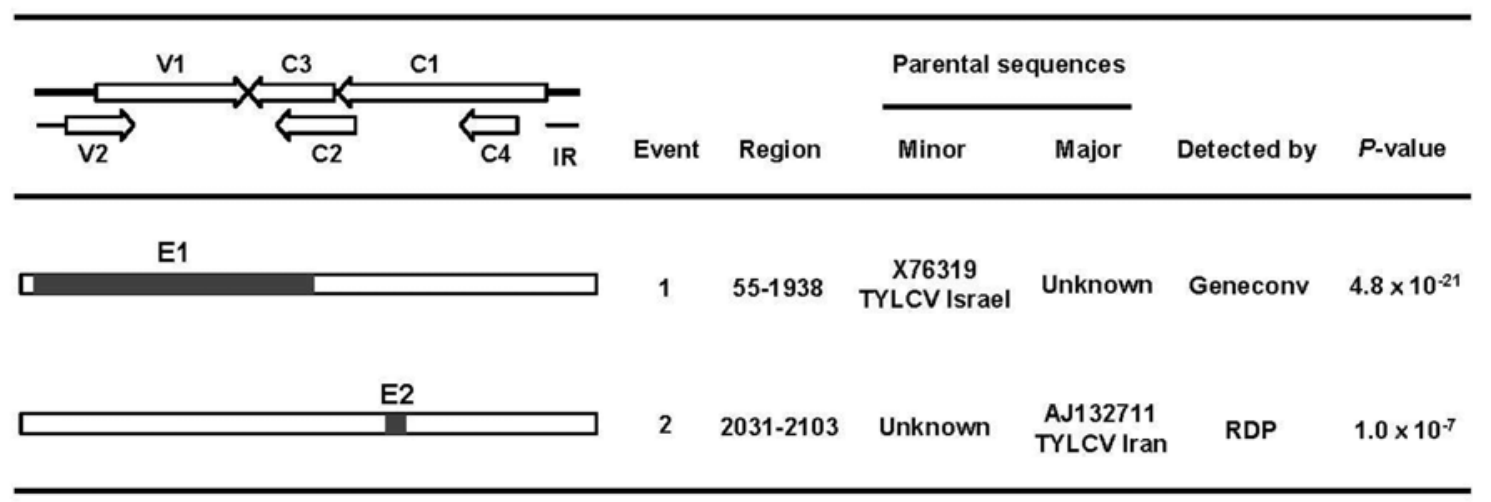

Fig. 2. Recombination spot by nucleotide transversions. Recombinant regions detected in the TYLCV sequence using RDP3. Event 1 (E1) revealed recombination between an unknown isolate (TYLCV Thailand isolate; AF206674) as the major 'parent' and the TYLCV Israel isolate (X76319) as the minor 'parent'. The 'daughter' of this recombination event is the TYLCV Jeju isolate (HM130914). Event 2 (E2) revealed recombination between the TYLCV Iran isolate (AJ132711) as the major 'parent' and an unknown isolate (TbLCV Comoros isolate; AM701760) as the minor 'parent'. All the TYLCV-Kr isolates examined in this study can be considered to comprise the 'daughters' of the E2 recombination event. 
Table 1. Multi-alignment of a recombination spot (nucleotides 651-1170) in recombination event 1 (E1) of TYLCV KG2 isolates and the TYLCV Japan isolate (AB192966)

\begin{tabular}{lccccccccccc}
\hline \hline \multirow{2}{*}{ Virus name } & \multicolumn{10}{c}{ Sequence number } \\
\cline { 2 - 11 } & 702 & 710 & 716 & 751 & 752 & 799 & 802 & 820 & 895 & 973 & 1102 \\
\hline TYLCV-KR[KR:Jj:08] (HM130914) & T & G & G & T & G & A & G & A & A & C & T \\
TYLCV-KR[KR:Jej:08] (HM130913) & A & C & A & A & A & G & C & G & G & G & A \\
TYLCV-KR[KR:Ns:09] (HM856918) & A & C & A & A & A & G & C & G & G & G & A \\
TYLCV-KR[KR:Is:09] (HM856916) & A & C & A & A & A & G & C & G & G & G & A \\
TYLCV-IL[JR:Han:05] (AB192966) & A & C & A & A & A & G & C & G & G & G & A \\
\hline
\end{tabular}

an unknown major 'parent' (TYLCV Thailand isolate; AF206674) and the TYLCV Israel isolate (X76319) as a minor 'parent', and was identified only in the TYLCV isolate from Jeju (HM130914). E1 was detected with a high degree of confidence by all seven recombination detection methods using original RDP (average $P$-value $=1.894 \times 10^{-16}$ ), Geneconv (average $P$-value $=4.897 \times 10^{-21}$ ), Bootscan $($ average $P$-value $=8.430 \times 10^{-19}$ ), MaxChi (average $P$-value $=$ $1.062 \times 10^{-14}$ ), Chimaera (average $P$-value $=2.921 \times 10^{-10}$ ), SiScan (average $P$-value $=1.399 \times 10^{-58}$ ), and 3Seq (average $P$-value $=4.207 \times 10^{-20}$ ). In E1, a region (nucleotides 55-1938) of TYLCV Jeju was covered in the intergenic region (IR), virion sense (V1 and V2), and complementary sense (C2 and C3) sequences (Fig. 2). Recombination event 2 (E2) was observed between the TYLCV Iran isolate (AJ132711) as the major 'parent' and an unknown isolate (TbLCV Comoros isolate; AM701760) as the minor 'parent'. E2 was identified by RDP (average $P$-value $=$ $1.018 \times 10^{-7}$ ), MaxChi (average $P$-value $=2.040 \times 10^{-2}$ ), and 3Seq (average $P$-value $=1.711 \times 10^{-4}$ ) (Fig. 2). Multisequence alignment of the KG2 TYLCV isolates demonstrated six transversions between the Jeju isolate and the other three Korea KG2 isolates (Nonsan, Jeonju, and Iksan) at positions from 55 to 1938 in the DNA-A (Table 1 and Table 2).

The TYLCV Jeju (HM130914) isolate differed from the other TYLCV-Kr isolates in terms of its phylogenetic position, recombination pattern, and DNA sequence. These results can be attributed to the six nucleotide transversions in the DNA-A position from 702 to 1102 within ORF V1 and $\mathrm{C} 3$. The single nucleotide mutations shown in ORF V1 and $\mathrm{C} 3$ of the TYLCV Jeju isolate among the TYLCV-Kr isolates were caused by (1) transversions such as three [A to $\mathrm{T}$ ], one [G to $\mathrm{C}$ ], and two [C to G] changes and (2) transitions such as two [A to G] and two [G to A] (Table 1 and STable 1). Tamura (1992) previously noted the importance of understanding the numbers of nucleotide substitutions per site between DNA sequences when attempting to accurately estimate rates of molecular evolution. Unequal rates of transitions versus transversions, or transition-transversion bias, are included in models of sequence evolution.
Hagelberg et al. (1999) reported that six transversions in mitochondrial DNA (mtDNA) in different human mtDNA lineages may have been linked to occasional recombination events, and speculated that these six transversions constituted a recombination spot. Recombination spots are areas in or near which recombination occurs at higher-thanaverage frequencies. Smith (1994) proposed that recombination hot spots contain nucleotide sequences that are recognized by proteins that promote, directly or indirectly, a rate-limiting recombination step. In particular, the three [A to T] conversions at 702, 751, and 1102 bases in TYLCV Jeju ORF V1 and C3 may be critical transversions for E1 recombination event noted in the TYLCV Jeju isolate (Table 1 and Table 2). Critical [A to T] conversions have been observed in several experimental systems. Picketts et al. (1992) previously demonstrated that an [A to T] transversion in the factor IX promoter causes Hemophilia B. An [A to $\mathrm{T}$ ] transversion at position -5 of the factor IX gene has been shown to perform a crucial role in the developmental regulation of this gene through the binding of specific transcription factors.

According to the results of phylogenetic analysis, TYLCV$\mathrm{Kr}$ isolates evolved from Japan isolates (Lee et al., 2010). TYLCV KG1 and KG2 appear to have entered into Korea via two different routes. Among the TYLCV KG2 isolates, the TYLCV Jeju isolate was introduced to the inland provinces (Jeolla-do and Chungcheong-do) first, and appears subsequently to have spread to Jeju-do. Jeju-do is geographically isolated, and its annual average temperature is mild. Therefore, the TYLCV insect vector, Bemisia tabaci, winters in and outside of greenhouses in Jeju-do and delivers TYLCV to a variety of intermediate hosts yearround. The favorable TYLCV infection environment in Jeju-do may have resulted in more frequent single nucleotide mutations, such as transversions/transitions and recombination events, in TYLCV isolates from this area as compared to other Korea isolates from inland regions. We have currently set up the experiments to see the microevolution or sequence variations of TYLCV in controlled chambers in which tomatoes and other intermediate hosts were grown with TYLCV viruliferous whiteflies. Com- 
Table 2. TYLCV and TbLCV isolates used in phylogenetic and recombination analysis

\begin{tabular}{|c|c|c|c|c|}
\hline Virus isolate & $\begin{array}{l}\text { GenBank } \\
\text { No. }\end{array}$ & Virus name & $\begin{array}{l}\text { Size } \\
\text { (base) }\end{array}$ & Nation \\
\hline TYLCMLV-ML[ML:03] & AY502934 & Tomato yellow leaf curl Mali virus & 2794 & Mali \\
\hline TYLCV-IL[JR:Omu:Ng] & AB110217 & Tomato yellow leaf curl virus - Israel [Japan: Nagasiki, Omura] & 2774 & Japan \\
\hline TYLCV-IL[DO] & AF024715 & Tomato yellow leaf curl virus - [Dominican Republic] & 2781 & Dominican Republi \\
\hline TYLCV-Mld[PT:04] & AF105975 & Tomato yellow leaf curl virus - Mild [Portugal] & 2793 & Portugal \\
\hline TYLCV-Mld[ES:72:97] & AF071228 & Tomato yellow leaf curl virus - Mild [Spain7297] & 2791 & Spain \\
\hline TYLCCNV-Sha[CN:SH3:09] & FN256258 & Tomato yellow leaf curl virus $\mathrm{SH} 3$ & 2781 & China \\
\hline TYLCV-Mld[JR:Aic] & AB014347 & Tomato yellow leaf curl virus - Mild [Aichi] & 2787 & Japan \\
\hline TYLCCNV-Zhe[CN:ZJHZ1:09 & ]FN252890 & Tomato yellow leaf curl virus isolate ZJHZ1 & 2781 & China \\
\hline TYLCMLV-ET[ET:Mel:05] & DQ358913 & Tomato yellow leaf curl Mali virus - [Ethiopia] & 2785 & Ethiopia \\
\hline TYLCV-IL[EG:Ism] & AY594174 & Tomato yellow leaf curl virus from Egypt & 2781 & Egypt \\
\hline TYLCV-Mld[JO:Ju:08]. & GQ861427 & Tomato yellow leaf curl virus Mld [JO:Ju:08] & 2791 & Jordan \\
\hline TYLCSV-ES[ES:Alm:99] & NC_004005 & Tomato yellow leaf curl virus & 2781 & Spain \\
\hline TYLCV-IR[IR:Ira:98] & AJ132711 & Tomato yellow leaf curl virus - Iran & 2771 & Iran \\
\hline TYLCV-OM[OM:Alb:05] & DQ644565 & Tomato yellow leaf curl virus isolate Al-Batinah & 2765 & Oman \\
\hline TYLCV-IL[US:Flo] & AY530931 & Tomato yellow leaf curl virus, complete genome & 2781 & USA \\
\hline TYLCV-MX[MX:Gua:10] & FJ609655 & Tomato yellow leaf curl virus isolate Guasave & 2781 & Mexico \\
\hline TYLCV-MX[MX:Gua:09] & FJ012358 & Tomato yellow leaf curl virus isolate Guasave & 2781 & Mexico \\
\hline TYLCMLV-ML[Cam:07] & FM212663 & Tomato yellow leaf curl Mali virus complete genome & 2793 & Cameroon \\
\hline TYLCV-IL[JR:Han:05] & AB192966 & Tomato yellow leaf curl virus - Israel [Japan: Haruno] & 2781 & Japan \\
\hline TYLCV-IR[IR:Aba] & FJ355946 & Tomato yellow leaf curl virus strain Abadeh & 2782 & Iran \\
\hline TYLCV-Mld[JR:Yai] & AB116632 & Tomato yellow leaf curl virus - Mild [Japan: Yaizu] & 2791 & Japan \\
\hline TYLCV-IL[JR:Miy] & AB116629 & Tomato yellow leaf curl virus - Israel [Japan: Miyazaki] & 2774 & Japan \\
\hline TYLCV-NET[Net:08]:: & FJ439569 & Tomato yellow leaf curl virus from Netherlands & 2781 & Netherlands \\
\hline TYLCMLV-ML[ML:GHK2:10 & ]EU847740 & Tomato yellow leaf curl Mali virus - GHK2 & 2792 & Ghana \\
\hline TYLCV-IL[Mo:Bar:05] & EF060196 & Tomato yellow leaf curl virus - Moroccan & 2781 & Morocco \\
\hline TYLCV-IL[US:Ari] & EF210554 & Tomato yellow leaf curl virus - USA [Arizona] & 2752 & USA \\
\hline TYLCV-IL[TN:05] & EF101929 & Tomato yellow leaf curl virus - [Tunisia] & 2781 & Tunisia \\
\hline TYLCV-Mld[Re:02] & AJ865337 & Tomato yellow leaf curl virus - Mild [Reunion] & 2791 & Reunion \\
\hline TYLCV-Mld[ILB;LBA44:05] & EF185318 & Tomato yellow leaf curl virus - Lebanon [LBa4] & 2790 & Lebanon \\
\hline TYLCV-IL[TR:Mer:05] & AJ812277 & Tomato yellow leaf curl virus - Mersin 1 & 2781 & Turkey \\
\hline TYLCV-Mld[IL:93] & X76319 & Tomato yellow leaf curl virus - Mild & 2790 & Israel \\
\hline TbLCV-[Com:07] & AM701760 & Tobacco leaf curl Comoros virus & 2755 & Comoros \\
\hline TbLCV-KR[KR:Is:08] & HM164541 & Tobacco leaf curl virus - Korea Iksan & 2763 & Korea \\
\hline TbLCV-KR[KR:Jj:08] & HM164545 & Tobacco leaf curl virus - Korea Jeju & 2766 & Korea \\
\hline TbLCV-KR[KR:Gj:08] & HM164547 & Tobacco leaf curl virus - Korea Gimje & 2762 & Korea \\
\hline TbLCV-KR[KR:Sc:08] & HM164550 & Tobacco leaf curl virus - Korea Sunchang & 2763 & Korea \\
\hline TYLCV-IL[IL:Reo:86] & $\mathrm{X} 15656$ & Tomato yellow leaf curl virus TYLCV virion DNA & 2787 & Israel \\
\hline TYLCV-IL[CU] & $\mathrm{AJ} 223505$ & Tomato yellow leaf curl virus - [Cuba] & 2781 & Cuba \\
\hline TYLCTHV[Th:07] & DQ871222 & Tomato yellow leaf curl Thailand virus & 2747 & Thailand \\
\hline TYLCV-IL[PR:01] & AY134494 & Tomato yellow leaf curl virus - [Puerto Rico] & 2781 & Puerto Rico \\
\hline TYLCV-KR[KR:Jj:08] & HM130914 & Tomato yellow leaf curl Korea Jeju virus & 2781 & In this study \\
\hline TYLCV-KR[KR:Ms:08] & HM130912 & Tomato yellow leaf curl virus - Korea Masan & 2774 & In this study \\
\hline TYLCV-KR[KR:Jej:08] & HM130913 & Tomato yellow leaf curl virus - Korea Jeonju & 2781 & In this study \\
\hline TYLCV-KR[KR:Ns:09] & HM856918 & Tomato yellow leaf curl virus - Korea Nonsan & 2781 & In this study \\
\hline TYLCV-KR[KR:Is:09] & HM856916 & Tomato yellow leaf curl virus - Korea Iksan & 2781 & In this study \\
\hline TYLCV-KR[KR:Bus:09] & HМ856909 & Tomato yellow leaf curl virus - Korea Busan & 2774 & In this study \\
\hline TYLCV-KR[KR:Gw:09] & HM856912 & Tomato yellow leaf curl virus - Korea Gunwi & 2774 & In this study \\
\hline TYLCV-KR[KR:Gyj:09] & HМ856915 & Tomato yellow leaf curl virus - Korea Gyeongju & 2774 & In this study \\
\hline TYLCV-KR[KR:Gos:08] & HM856911 & Tomato yellow leaf curl virus - Korea Goseong & 2774 & In this study \\
\hline TYLCV-KR[KR:Us:09] & HM856919 & Tomato yellow leaf curl virus - Korea Uiseong & 2774 & In this study \\
\hline TYLCV-KR[KR:Gwj:09] & HM856913 & Tomato yellow leaf curl virus - Korea Gwangju & 2774 & In this study \\
\hline TYLCV-KR[KR:Jh:09] & HM856917 & Tomato yellow leaf curl virus - Korea Jangheung & 2774 & In this study \\
\hline TYLCV-KR[KR:Gwy:09] & HM856914 & Tomato yellow leaf curl virus - Korea Gwangyang & 2774 & In this study \\
\hline
\end{tabular}


parisons of the sequence of the TYLCV-Jeju isolate (HM130914) and a possible TYLCV Jeju isolate which was originally from TYLCV Japan Haruno (AB192966) revealed that the TYLCV Japan isolate had none of the nucleotide transversions and transitions in the recombination event $\mathrm{E} 1$ that had been previously identified in the TYLCV Jeju isolate (Table 1 and Table 2). Taken together, our findings indicate that the recombination E1 pattern of the TYLCV Jeju isolate may have arisen as the result of natural mutations induced by nucleotide transversions and transitions in a recombination spot.

\section{Acknowledgements}

This research was supported by a grant from the BioGreen21 Agenda program (No. PJ006325) of the Rural Development Administration (RDA) in Korea.

\section{References}

Bonilla-Ramirez, G. M., Guevara-Gonzalez, R. G., GarzonTiznado, J. A., Ascencio-Ibanez, J. T., Torres-Pacheco, I. and Rivera-Bustamante, R. F. 1997. Analysis of the infectivity of monomeric clones of Pepper huasteco virus. J. Gen. Virol. 78:947-951.

Briddon, R. W., Bedford, I. D., Tsai, J. H. and Markham, P. G. 1996. Analysis of the nucleotide sequence of the treehoppertransmitted geminivirus, Tomato pseudo-curly top virus, suggests a recombinant origin. Virology 219:387-394.

Garcia-Andres, S., Tomas, D. M., Sanchez-Campos, S., NavasCastillo, J. and Moriones, E. 2007. Frequent occurrence of recombinants in mixed infections of tomato yellow leaf curl disease associated begomoviruses. Virology 365:210-219.

Choi, K. J., Kim, W. G., Kim, H. G., Choi, H. W., Lee, Y. K., Lee, B. D., Lee, S. Y. and Hong, S. K. 2011. Morphology, molecular phylogeny and pathogenecity of Colletotrichum panacicola causing anthracnose of Korean ginseng. Plant Pathol. J. 27:1-7.

Davino, S., Napoli, C., Dellacroce, C., Miozzi, L., Noris, E., Davino, M. and Accotto, G. P. 2009. Two new natural begomovirus recombinants associated with the Tomato yellow leaf curl disease co-exist with parental viruses in tomato epidemics in Italy. Virus Res. 143:15-23.

Duffy, S. and Holmes, E. C. 2008. Phylogenetic evidence for rapid rates of molecular evolution in the single-stranded DNA begomovirus Tomato yellow leaf curl virus. J. Virol. 82:957965.

Edgar, R. C. 2004. MUSCLE: a multiple sequence alignment method with reduced time and space complexity. BMC Bioinform. 5:113.

Fondong, V. N., Pita, J. S., Rey, M. E., de Kochko, A., Beachy, R. N. and Fauquet, C. M. 2000. Evidence of synergism between African cassava mosaic virus and a new double recombinant geminivirus infecting cassava in Cameroon. J. Gen. Virol.
81:287-297.

Ge, L., Zhang, J., Zhou, X. and Li, H. 2007. Genetic structure and population variability of Tomato yellow leaf curl China virus. J. Virol. 81:5902-5907.

Hagelberg, E., Goldman, N., Lió, P., Whelan, S., Schiefenhöel, W., Clegg, J. B. and Bowden, D. K. 1999. Evidence for mitochondrial DNA recombination in a human population of island Melanesia. Proc. Biol. Sci. 266:485-492.

Idris, A. M. and Brown, J. K. 2005. Evidence for interspecificrecombination for three monopartite begomoviral genomes associated with the Tomato leaf curl disease from central Sudan. Arch. Virol. 150:1003-1012.

Jonson, M. G., Seo, J. K., Choi, H. S., Kim, J. S. and Kim, K. H. 2009. Effects of recombination on the pathogenicity and evolution of Pepper mottle virus. Plant Pathol. J. 25:417-421.

Kim, J. S., Cho, J. D., Choi, H. S., Lee, S. H., Choi, G. S., Lee, S. Y., Kim, H. J. and Yoon, M. K. 2010. Ribgrass mosaic Tobamovirus occurred on chinese cabbage in Korea. Plant Pathol. J. 26:328-339.

Klute, K. A., Nadler, S. A. and Stenger, D. C. 1996. Horseradish curly top virus is a distinct subgroup II geminivirus species with rep and $\mathrm{C} 4$ genes derived from a subgroup III ancestor. $J$. Gen. Virol. 77:1369-1378.

Lefeuvre, P., Martin, D. P., Harkins, G., Lemey, P. and Gray, A. J. A. 2010. The spread of Tomato yellow leaf curl virus from the Middle East to the world. PLoS Pathog. 6:e1001164.

Lee, H., Song, W., Kwak, H. R., Kim, J. D., Park, J., Auh, C. K., Kim, D. H., Lee, K. Y., Lee, S. and Choi, H. S. 2010. Phylogenetic analysis and inflow route of Tomato yellow leaf curl virus (TYLCV) and Bemisia tabaci in Korea. Mol. Cells 30:467-476.

Martin, D. P., Lemey, P., Lott, M., Moulton, V., Posada, D. and Lefeuvre, P. 2010. RDP3: a flexible and fast computer program for analyzing recombination. Bioinformatics 26:24622463.

Monci, F., Sanchez-Campos, S., Navas-Castillo, J. and Moriones, E. 2002. A natural recombinant between the geminiviruses Tomato yellow leaf curl Sardinia virus and Tomato yellow leaf curl virus exhibits a novel pathogenic phenotype and is becoming prevalent in Spanish populations. Virology 303:317-326.

Navas-Castillo, J., Sanchez-Campos, S., Noris, E., Louro, D., Accotto, G. P. and Moriones, E. 2000. Natural recombination between Tomato yellow leaf curl virus-Is and Tomato leaf curl virus. J. Gen. Virol. 81:2797-2801.

Padidam, M., Sawyer, S. and Fauquet, C. M. 1999. Possible emergence of new geminiviruses by frequent recombination. Virology 265:218-225.

Picketts, D. J., D'Souza, C., Bridge, P. J. and Lillicrap, D. 1992. An A to $T$ transversion at position -5 of the factor IX promoter results in hemophilia B. Genomics 12:161-163.

Saitou, N. and Nei, M. 1987. The neighbor-joining method: a new method for reconstructing phylogenetic trees. Mol. Biol. Evol. 4:406-425.

Sanz, A. I., Fraile, A., Garcia-Arenal, F., Zhou, X., Robinson, D. J., Khalid, S., Butt, T. and Harrison, B. D. 2000. Multiple 
infection, recombination and genome relationships among begomovirus isolates found in cotton and other plants in Pakistan. J. Gen. Virol. 81:1839-1849.

Saunders, K. and Stanley, J. 1999. A nanovirus-like DNA component associated with yellow vein disease of Ageratum conyzoides: evidence for interfamilial recombination between plant DNA viruses. Virology 264:142-152.

Schneider, W. L. and Roossinck, M. J. 2001. Genetic diversity in RNA virus quasispecies is controlled by host-virus interactions. J. Virol. 75:6566-6571.

Smith, G. R. 1994. Hotspots of homologous recombination. Cell. Mol. Life Sci. 50:234-241.

Tamura, K. 1992. Estimation of the number of nucleotide substitutions when there are strong transition-transversion and $\mathrm{G}+$ C-content biases. Mol. Biol. Evol. 9:678.

Tamura, K., Dudley, J., Nei, M. and Kumar, S. 2007. MEGA 4: Molecular evolutionary genetics analysis (MEGA) software version 4.0. Mol. Biol. Evol. 24:1596-1599.

Torres-Pacheco, I., Garzon-Tiznado, J. A., Herrera-Estrella, L. and Rivera-Bustamante, R. F. 1993. Complete nucleotide sequence of Pepper huasteco virus: analysis and comparison with bipartite geminiviruses. J. Gen. Virol. 74:2225-2231.

Umaharan, P., Padidam, M., Phelps, R. H., Beachy, R. N. and Fauquet, C. M. 1998. Distribution and diversity of geminiviruses in Trinidad and Tobago. Phytopathology 88:1262-1268.

Zhou, X., Liu, Y., Calvert, L., Munoz, C., Otim-Nape, G. W., Robinson, D. J. and Harrison, B. D. 1997. Evidence that DNA-A of a geminivirus associated with severe cassava mosaic disease in Uganda has arisen by interspecific recombination. $J$. Gen. Virol. 78:2101-2111.

Zhou, X., Liu, Y., Robinson, D. J. and Harrison, B. D. 1998. Four DNA-A variants among Pakistani isolates of cotton leaf curl virus and their affinities to DNA-A of geminivirus isolates from okra. J. Gen. Virol. 79:915-923. 